УДК $347.73 ; 342.55$

DOI https://doi.org/10.32837/pyuv.v0i2(27).186

С. А.Семенченко кандидат юридичних наук, начальник управління доходів Департаменту фінансів Харківської обласної державної адміністраиї

\title{
ДОХОДИ МІСЦЕВИХ БЮДЖЕТІВ ЯК ПРАВОВА КАТЕГОРІЯ
}

Місцеві доходи є важливою складовою частиною бюджетних доходів. Проте, незважаючи на ïх роль у становленні дієздатної та ефективної місцевої влади, перетворенні її на вагомий інструмент соціально-економічного розвитку територій, дослідженню доходів місцевих бюджетів приділялось мало уваги. Правове регулювання доходів місцевих бюджетів у вітчизняній літературі вивчалось та досліджувалось переважно крізь призму доходів державного бюджету, що зумовлено формуванням місцевих бюджетів здебільшого коштом загальнодержавних податків і зборів, а також тим, що місцеві бюджети як самостійна ланка бюджетної системи України виникли практично після проголошення незалежності України. До того часу місцеві бюджети були складником державного бюджету [1, с. 20-21].

Метою статті $є$ визначення правової природи доходів місцевих бюджету, дослідження їх характерних ознак, встановлення відмінності між терміном «доходи місцевих бюджетів» та суміжними поняттями.

Розуміння доходів бюджету як відносин, що пов'язані $з$ надходженням коштів до особливого фонду коштів - бюджету, є поширеним та міститься в працях багатьох сучасних науковців [1, с. 19; 2, с. 139-148]. Водночас для поглибленого вивчення предмета цікаво простежити еволюцію поняття «доходи місцевих бюджетів» у фінансовій науці. До XIX ст. термін «доходи місцевих бюджетів» не використовувався, а доходи місцевої влади разом із доходами центральної влади трактувалися як державні або публічні. А. Сміт у своїй праці «Багатство нації. Дослідження про природу та причини багатства націй» перший висловив доцільність розмежування державних та місцевих бюджетів i, відповідно, їх доходів. Він наголошував, що, крім державного фінансового господарства, існує ще й місцеве фінансове господарство, виділяючи такі види доходів, як неподаткові (доходи від капіталів, підприємств, майна держави) і податки [3].

Виокремленню та дослідженню питань доходів місцевих бюджетів у фінансовій науці сприяла земська реформа $1864 \mathrm{p}$. Різні аспекти цих питань знайшли відображення у працях О.I. Васильчикова, В.О. Лебедєва, С.Б. Веселовського, І.Х. Озерова, А.М. Свірщевського, В.Н. Твердохлєбова, які під доходами місцевих бюджетів розуміли сукупність ресурсів, що нагромаджувались місцевими самоврядними спілками, підпорядкованими державі для задоволення громадських потреб $[4$, c. 116].

Дослідження доходів місцевих бюджетів тривало за радянських часів. Так, М.М. Ровінський у 1944 р. вказував на цільове використання доходів місцевих бюджетів; групуючи доходи за ознакою стягнення, він розрізняв податкові надходження та доходи, які є результатом господарської діяльності місцевих органів влади [5, с. 9]. Безумовно, треба враховувати, що господарська діяльність місцевих органів влади була практично непомітною. Місцеві органи влади як під час Другої світової війни, так і раніше реалізовували делеговані їм повноваження за рахунок фінансування із Державного бюджету СРСР.

Найбільшого розвитку дослідження питань сутності доходів місцевих бюджетів у фінансовій науці набули в часи незалежності України. Формування концептуальних засад доходів місцевих бюджетів у цей час тісно пов'язане із визнанням місцевого самоврядування та розширенням фінансової незалежності місцевих органів влади.

Розглядаючи еволюцію методологічних та теоретичних підходів до визначення доходів місцевих бюджетів, 0.О. Сунцова дійшла обгрунтованих висновків, що науковці досить часто обмежуються тільки одним із підходів до визначення суті поняття «доходи місцевих бюджетів» - або економічним, або юридичним [6, с. 8]. O.Р. Романенко під доходами бюджету як економічною категорією розуміє економічні відносини, що виникають у держави з юридичними і фізичними особами у процесі формування бюджетного фонду країни [7, с. 164-165]. А.М. Бабич та Л.Н. Павлова трактують доходи бюджетів як частину національного доходу, що централізується в бюджетах різних рівнів [8, с. 185]. К.Ю. Чуловський доходи місцевих бюджетів визначає як грошові кошти, що надходять у безповоротному, безвідплатному або відплатному порядку відповідно до законодавства країни в розпорядження органів місцевого самоврядування 3 метою створення основи, необхідної для фінансування їх діяльності, за винятком коштів, що є джерелами фінансування дефіциту бюджету [9, с. 6].

3 нашого погляду, принципово розривати економічну і правову природу явища у фінансовій 
сфері недоречно і неможливо. Доходам бюджету, як складовій частині бюджету, притаманна його природа. Так, доходи бюджету як економічну конструкцію необхідно розглядати як частину публічних грошових коштів, як сукупність відповідних економічних відносин, але при цьому не можна забувати про те, що бюджет (у тому числі дохідна частина бюджету) стає бюджетом лише з моменту прийняття відповідного законодавчого акта (закону чи рішення місцевої ради). Саме з цього часу «оживають» всі економічні аспекти життя такого явища і виникають відповідні бюджетні права та обов'язки учасників відносин, засоби, які забезпечують їх дотримання, можливість застосування примусу у разі порушення відповідної норми.

Доволі грунтовною у цьому питанні є позиція О.Г. Пауля, який, трактуючи поняття «доходи бюджету», проводить аналогію з різними підходами до розуміння бюджету у фінансовому праві та виділяе їх матеріальну, правову й економічну природу:

- як матеріальна категорія доходи бюджету являють собою грошові кошти, що надходять до бюджету на умовах безповоротності, а також кошти, що повертаються з бюджету як зайво сплачені, зайво стягнені та такі, що помилково надійшли до бюджету;

- доходи бюджету як правова категорія - це бюджетні показники, що визначають прогнозований обсяг доходів бюджету та нормативи розподілу доходів між бюджетами;

- доходи бюджету як економічна категорія являють собою сукупність економічних відносин, пов'язаних із формуванням фінансових ресурсів відповідного бюджету на безповоротній основі [10, с. 21-22].

Аналізуючи категорію «доходи бюджету», К.О. Токарева приділяє особливу увагу виокремленню характерних ознак доходів бюджету, до яких зараховує: грошовий характер - мають грошове, а не натуральне вираження; різноманітність джерел отримання, перелік яких чітко визначений бюджетним законодавством; правова визначеність - поняття та склад доходів, їх класифікація закріплені в нормах Бюджетного кодексу України та у підзаконних актах; тимчасовість - доходи акумулюються певний проміжок часу, що зумовлено темпоральною дією закону (рішення) про бюджет та існуванням бюджетного періоду; публічний характер - спрямованість на задоволення публічного інтересу; плановість - за загальним правилом, їх обсяг у відповідному бюджеті планується заздалегідь; процесуальність законом встановлена процедура перерахування коштів до бюджету з моменту сплати певних коштів до їх зарахування до відповідного бюджету; безповоротність - при встановленні доходів не передбачається необхідність їх повернення. Остання ознака, на думку К.О. Токаревої, є специфічною, оскільки притаманна не всім доходам бюджету, а лише певним видам (наприклад податковим) [11, с. 9].

Водночас 0.Г. Пауль, розглядаючи таку важливу ознаку доходів бюджету, як безповоротність, зазначає, що грошові кошти, які повертаються з бюджету як зайво сплачені, зайво стягнені або помилково зараховані до бюджету, включаються в поняття «доходи». При цьому безповоротність доходів бюджету не вступає в колізію з можливістю їх повернення, оскільки таке повернення здійснюється не 3 огляду на раніше встановлене зобов'язання держави повернути ці кошти, а на основі інших норм [10, с. 22]. Вважаємо, що ознака поворотності коштів має регулюватися поза межами бюджетних правовідносин, оскільки повернення незаконно стягнутих або зайво сплачених податків та зборів - це відносини, що цілком врегульовані податково-правовими нормами. Може йтися лише про певну межу бюджетно-податкового регулювання.

У законодавстві України доходи бюджету також наділені ознакою безповоротності. Так, відповідно до ст. 2 Бюджетного кодексу України [12] доходами бюджету є податкові, неподаткові та інші надходження на безповоротній основі, справляння яких передбачено законодавством України (включаючи трансферти, плату за надання адміністративних послуг, власні надходження бюджетних установ). Щодо визначення в Бюджетному кодексі України терміна "доходи бюджету» 3.I. Перощук зауважує, що воно характеризує лише структуру доходів бюджету, визначаючи їх як сукупність певних надходжень до бюджету [13, c. 173].

Також у ст. 2 Бюджетного кодексу України міститься визначення поняття «надходження до бюджету» - доходи бюджету та кошти, залучені в результаті взяття боргових зобов'язань органами державної влади, органами влади Автономної Республіки Крим або органами місцевого самоврядування. Для встановлення відмінності між поняттями «надходження бюджету» та «доходи бюджету» в чинному бюджетному законодавстві України доцільно звернутися до Порядку казначейського обслуговування доходів та інших надходжень державного бюджету, затвердженого Наказом Міністерства фінансів України від 29.01.2013 р. № 43 (зі змінами) [14]. У зазначеному Порядку, а саме п. 1.2. розділу I «Загальні положення» вказано, що цей Порядок визначає процедури казначейського обслуговування доходів та інших надходжень державного бюджету, в тому числі надходжень від повернення бюджетних позичок, фінансової допомоги, наданої на поворотній основі та кредитів, у тому числі залучених державою або під державні гарантії. За результатами 
аналізу наведених вище нормативно-правових актів України можна зробити висновок, що законодавець зараховує до надходжень бюджету не тільки доходи як надходження на безповоротній основі, а й бюджетні кошти, надані на поворотній основі, - кредити, позички, фінансову допомогу.

Варто також зазначити, що у фінансовій літературі зустрічаються різні погляди стосовно зарахування запозичень до доходів бюджетів. Більшість вчених виділяють їх як джерела поповнення бюджетних коштів, а деякі - як різновид доходів бюджету. П.М. Годме пише: «Державні ресурси дуже різноманітні, але вони можуть бути зведені до двох основних категорій: позики і податки» [15, с. 343]. Вважаємо, що відповідно до чинного законодавства України запозичення не являють собою дохід бюджету, оскільки підлягають поверненню, а тому не відповідають ознаці безповоротності доходів. Дійсно, строкова позика, на перший погляд, може сприйматися як певне надходження, але після спливу строку вона має бути не лише повернута, а й додатково погашені відсотки за користування нею, при цьому коштів повертається більше, ніж було позичено. 3 огляду на зазначене слушною видається постановка питання не про доходи бюджети, а про його видатки.

O.A. Музика-Стефанчук, так само як i О.Г. Пауль, наголошує на відмінності між поняттями «доходи бюджету» i «дохідна частина бюджету», пояснюючи це тим, що дохідна частина бюджету - це частина фінансового плану, а доходи бюджету - це вже реальні надходження до бюджету [1, с. 21-22]. 3 таким твердженням у теоретичному сенсі можна погодитись, проте на практиці таке розмежування особливого значення не має, а використовується узагальнений термін «доходи» .

Проблемою вживаних законодавчих категорій, 3 яких складається горизонтальна структура місцевих бюджетів, займалася О.А. Музика-Стефанчук у процесі дослідження неподаткових доходів місцевих бюджетів України. Вчена вказує, що «місцевий бюджет складається із надходжень (доходів бюджетів та коштів, залучених у результаті взяття боргових зобов'язань органами державної влади, органами АРК або органами місцевого самоврядування) і витрат (видатків бюджету і коштів на погашення основної суми боргу)» [1, с. 22]. Однак обгрунтування цього вчена бере в законодавчому закріпленні структури місцевих бюджетів, наданій у ст. 63 Бюджетного кодексу України: «Місцевий бюджет відповідно до цього Кодексу містить надходження і витрати на виконання повноважень органів влади Автономної Республіки Крим, місцевих державних адміністрацій та органів місцевого самоврядування. Ці надходження і витрати становлять єдиний баланс відповідного бюджету» [12].

К.О. Токарєва, говорячи про структуру бюджету, наголошує на необхідності розрізняти його го- ризонтальну та вертикальну структуру та зазначає, що горизонтальну структуру бюджетів формують доходи та видатки таких бюджетів, тоді як вертикальну - загальний і спеціальний фонди [11, с. 14]. На нашу думку, термінологічно більш доречно здійснювати поділ місцевих бюджетів на частину бюджетних надходжень та частину бюджетних витрат, що узгоджується з позицією вітчизняного законодавця, оскільки глава 11 Бюджетного кодексу України має назву «Надходження та витрати місцевих бюджетів». Тому, застосовуючи поділ саме на надходження і витрати, ми охопимо усі без винятку канали руху грошових коштів бюджетів.

За результатами всебічного дослідження важливої складової частини горизонтальної структури місцевих бюджетів - доходів, встановлено, що за чинним бюджетним законодавством України доходи місцевих бюджетів є складовою частиною іншої частини структури місцевих бюджетів надходжень бюджету, а тому необхідно уникати ототожнення цих термінів. Так, у Бюджетному кодексі України дається визначення як поняття «доходи бюджету», так і поняття «надходження бюджету», при цьому до складу останнього законодавець зараховує не тільки доходи, як надходження на безповоротній основі, але й бюджетні кошти, надані на поворотній основі, - кредити, позички, фінансову допомогу. Тобто основна відмінність між цими поняттями проявляється саме у процесі дослідження такої характерної ознаки доходів бюджету, як безповоротність бюджетних коштів.

Своєю чергою, категорію «доходи місцевих бюджетів» проаналізовано з використанням різних підходів до розуміння бюджету у фінансовому праві. Вважаємо, що під доходами місцевих бюджетів варто розуміти частину публічних грошових коштів, яка відповідно до норм Бюджетного кодексу України, закону про Державний бюджет України на відповідний рік та рішень місцевих рад на безповоротній основі зараховується до місцевих бюджетів різних рівнів для задоволення потреб населення відповідної територіальної громади.

\section{Jimepamypa}

1. Музика О.А. Неподаткові доходи місцевих бюджетів України (фінансово-правове дослідження) : монографія. Київ : Атіка, 2006. 256 с.

2. Финансовое право России : учебное пособие / под ред. А.А. Ялбулганова. Москва : Статут, 2001. 362 с.

3. Сміт А. Добробут націй. Дослідження про природу та причини добробуту націй. Київ : Port-Royal, $2001.590 \mathrm{c}$.

4. Легкоступ I.I. Особливості формування місцевих бюджетів України та шляхи зміцнення їх дохідної бази. Формування ринкових відносин в Украӥні. 2010. № 3. С. $165-170$.

5. Ровинский Н.Н. Государственный бюджет СССР : учебное пособие для фин.-Экон. вузов. Москва : Госфиниздат, 1944. $385 \mathrm{c}$.

6. Сунцова 0.0. Доходи місцевих бюджетів в сучасних умовах : автореф. дис. ... канд. екон. наук : 08.04.01 
«Фінанси, грошовий обіг і кредит» / Ін-т аграр. економіки УААН. Київ, 2003. 20 с.

7. Романенко О.Р. Фінанси : підручник. Київ : Центр навч. л-ри. 2004. 312 с.

8. Бабич A.M. Государственные и муниципальные финансы / А.М. Бабич, Л.Н. Павлова. Москва : Юнити, 2000. 346 c.

9. Чуловский К.Ю. Правовое регулирование доходов местных бюджетов : автореф. дис. ... канд. юрид. наук : 12.00.14 / Ом. гос. ун-т им. Ф.М. Достоевского. Омск, 2009. 19 с.

10. Пауль А.Г. К вопросу о бюджетно-правовом понятии доходов бюджета. Финансовое право. 2011. № 2. С. 20-23.

11. Токарєва К.О. Структура бюджету: фінансово-правовий аналіз : автореф. ... канд. юрид. наук : 12.00.07. Харків, 2016. 20 с.

12. Бюджетний кодекс України від 8 липня 2010 p. № 2456-VI. Відомості Верховної Ради України. 2010. № 50. С. 1778 . Ст. 572.

13. Проблеми правового регулювання доходів та видатків бюджетів, що становлять бюджетну систему України / 3.I. Перощук. Актуальні проблели держави і права. 2014. Вип. 74. С. 172-177.

14. Про затвердження Порядку казначейського обслуговування доходів та інших надходжень державного бюджету : Наказ Міністерства фінансів України від 29.01.2013 р. № 43. Офіиійний вісник України. 2013. № 17. Ст. 592 .

15. Годме П.М. Финансовое право / пер. с фр. Р.О. Халфиной. Москва : Прогресс, 1978. 429 с.

\section{Анотація}

Семенченко C. A. Доходи місцевих бюджетів як правова категорія. - Стаття.

Статтю присвячено дослідженню доходів місцевих бюджету як правової категорії. Визначено місце доходів у горизонтальній структурі місцевих бюджетів, проаналізовано ключові підходи до визначення терміна «доходи місцевих бюджетів», встановлено відмінності між поняттями «надходження бюджету» та «доходи бюджету» у чинному бюджетному законодавстві України. Мета статті - визначення правової природи доходів місцевих бюджету, дослідження їх характерних ознак, встановлення відмінності між терміном «доходи місцевих бюджетів» та суміжними поняттями. Формування концептуальних засад доходів місцевих бюджетів у цей час тісно пов'язане із визнанням місцевого самоврядування та розширенням фінансової незалежності місцевих органів влади. Розкрито, що ознака поворотності коштів має регулюватися поза межами бюджетних правовідносин, оскільки повернення незаконно стягнутих або зайво сплачених податків та зборів - це відносини, що цілком врегульовані податково-правовими нормами. Може йтися лише про певну межу бюджетно-податкового регулювання. У законодавстві України доходи бюджету також наділені ознакою безповоротності. Так, відповідно до ст. 2 Бюджетного кодексу України доходами бюджету є податкові, неподаткові та інші надходження на безповоротній основі, справляння яких передбачено законодавством України (включаючи трансферти, плату за надання адміністративних послуг, власні надходження бюджетних установ). Досліджено, що у фінансовій літературі зустрічаються різні погляди стосовно зарахування запозичень до доходів бюджетів. Більшість вчених виділяють їх як джерела поповнення бюджетних коштів, а деякі - як різновид доходів бюджету. Розкрито, що відповідно до чинного законодавства України запозичення не являють собою дохід бюджету, оскільки підлягають поверненню, а тому не відповідають ознаці безповоротності доходів. Детально описана думка автора, що строкова позика, на перший погляд, може сприйматися як певне надходження, але після спливу строку не лише вона має бути повернута, а й додатково погашені відсотки за користування нею, при цьому коштів повертається більше, ніж було позичено. 3 огляду на зазначене, автором було припущена постановка питання не про доходи бюджети, а про його видатки. За результатами всебічного дослідження важливої складової частини горизонтальної структури місцевих бюджетів - доходів встановлено, що за чинним бюджетним законодавством України доходи місцевих бюджетів є складником іншої частини структури місцевих бюджетів - надходжень бюджету, а тому необхідно уникати ототожнення цих термінів.

Ключові слова: бюджет, бюджетна система, доходи бюджету, надходження бюджету, місцеві бюджети.

\section{Summary}

Semenchenko S. A. Local budget revenues as a legal category. - Article.

The article is devoted to the study of local budget revenues as a legal category. The place of revenues in the horizontal structure of local budgets is determined, the key approaches to the definition of the term "local budget revenues" are analyzed, the differences between the concepts of "budget revenues" and "budget revenues" in the current budget legislation of Ukraine are determined. The purpose of the article is to determine the legal nature of local budget revenues, to study their characteristics, to distinguish between the term "local budget revenues" and related concepts. Formation of conceptual bases of local budget revenues at this time is closely connected with recognition of local self-government and expansion of financial independence of local authorities. It has been revealed that the sign of recoverability of funds should be regulated beyond the limits of budgetary relations, since the return of illegally collected or paid taxes and fees is a relationship that is fully governed by tax rules. It can only be about a certain limit of fiscal regulation. In the legislation of Ukraine the budget revenues are also endowed with irreversibility. Thus, according to Art. 2 of the Budget Code of Ukraine budget revenues are tax, non-tax and other non-refundable revenues, which are provided by the legislation of Ukraine (including transfers, payment for administrative services, own revenues of budgetary institutions). It has been investigated that there are different views in the financial literature regarding the attribution of borrowing to budget revenues. Most scholars identify them as sources of replenishment, and some - as a kind of budget revenues. It is revealed that according to the current legislation of Ukraine, borrowings do not represent budget income as they are repayable and therefore do not correspond to the sign of irreversibility of income. The author's opinion is described in detail that a term loan may, at first glance, be perceived as a certain income, but after the expiration of the term it should not only be repaid, but additionally repaid interest for its use, with more money being repaid than it was borrowed. In view of the above, the author suggested that the question was not about budget revenues but about his expenditures. According to the results of a comprehensive study of an important component of the horizontal structure of local budgets - revenues, it is established that under the current budget legislation of Ukraine, local budget revenues are part of another part of the structure of local budgets - budget revenues, so it is necessary to avoid identifying these terms.

Key words: budget, budget system, budget revenues, budget receipts, local budgets. 